\title{
Acute abdomen in pregnancy: a case series on clinical presentation and diagnostic dilemma
}

\author{
G. R. Abhirami*, Chennaiahgari Sathyavani, Ravi N. Patil
}

Department of Obstetrics and Gynaecology, Bangalore Baptist Hospital, Bangalore, Karnataka, India

Received: 07 December 2020

Revised: 11 January 2021

Accepted: 12 January 2021

\author{
*Correspondence: \\ Dr. G. R. Abhirami, \\ E-mail: abhiramigr@gmail.com
}

Copyright: (C) the author(s), publisher and licensee Medip Academy. This is an open-access article distributed under the terms of the Creative Commons Attribution Non-Commercial License, which permits unrestricted non-commercial use, distribution, and reproduction in any medium, provided the original work is properly cited.

\begin{abstract}
Acute abdomen in pregnancy remains one of the most challenging situation in regard with the diagnosis and management. Pregnancy is a unique state in which the female body undergoes both anatomical and physiological changes which can pose a challenge in diagnosis. This may result in delay in management and increase in maternal and fetal morbidity and mortality. This study was to identify the spectrum of causes, the clinical presentation and diagnostic dilemma of acute abdomen in pregnancy. It was an observational study was done over a period of 3 years which included all the pregnant women who presented with acute abdomen. In this study, eighteen pregnant women presented with acute abdomen. Among the study group, 5.5\%, 50\% and 44.5\% presented in first, second and third trimester respectively. The diagnosis included acute appendicitis in $11.1 \%$, acute cholecystitis in $16.6 \%$, acute pancreatitis in $16.6 \%$, malrotation in $11.1 \%$, uterine rupture $11.1 \%$, rudimentary horn rupture in $22.4 \%$ and ovarian cyst torsion in $11.1 \%$. The clinical presentation included pain abdomen $(16.6 \%)$, pain abdomen and vomiting (44.4\%), pain abdomen in shock (39\%) and abdominal tenderness (33.3\%). The diagnosis was confirmed with ultrasonography in $55.6 \%, 11.1 \%$ women required higher imaging like magnetic resonance imaging (MRI) and 33.3\% women were diagnosed on table. Majority of them had good outcome, but there was one maternal mortality (6\%). Diagnosis and treatment of acute abdomen in pregnancy should be individualized. Good clinical acumen is essential for ordering early diagnostic test in acute abdomen in pregnancy. Appropriate intervention should be undertaken at the earliest to reduce the maternal and fetal complications.
\end{abstract}

Keywords: Acute abdomen, Clinical presentation, Imaging, Maternal mortality

\section{INTRODUCTION}

Acute abdomen accounts for 5-10\% of all emergency department visits. The causes are obstetric, gynecological, and many others which encompass a wide spectrum of surgical and medical conditions. Pregnant state complicates the issue because of anatomic and physiologic changes during pregnancy. Physical findings are less prominent compared to those in the non-pregnant state with the same disorder. ${ }^{1}$ Diagnosis of acute abdomen is challenging, requires careful history, thorough evaluation of symptoms, examination, and judicious use of investigations to specify the disease and management which many times could be surgery only. ${ }^{1}$

Leading problems in the diagnosis of acute abdomen during pregnancy are: expanding uterus, which displaces other intra-abdominal organs and thus makes physical examination very difficult, high prevalence of nausea, vomiting, and abdominal pain in the normal obstetric population and general reluctance to operate unnecessarily on a gravid patient. ${ }^{2}$

Why this study? Acute abdomen in pregnancy remains one of the most challenging situation in regard with the 
diagnosis and management. Accurate knowledge is essential for appropriate and timely decision. In our study, we aimed to give an overview of the causes of acute abdomen during pregnancy with special attention to the clinical presentation and diagnostic dilemma of such cases. We have included all the pregnant women who presented with acute abdomen due to rare causes and excluded the common causes like ectopic pregnancy, abruption. The cases were analysed based on the trimester, clinical presentation and diagnostic methods utilized.

\section{CASE SERIES}

In the study, eighteen women were included who presented with acute abdomen in pregnancy. Among eighteen women, the age distribution showed $9(50 \%)$ in 21-25 years, 7 (39\%) in 26-30 years, $1(5.5 \%)$ in $31-35$ years and $1(5.5 \%)$ in $36-40$ years.

\section{Medical causes}

\section{Acute pancreatitis}

There were three cases of acute pancreatitis. They presented at third trimester with epigastric pain, vomiting and epigastric tenderness. Symptoms did not subside with routine treatment given for gastritis. Hence further investigations were carried out which revealed raised serum amylase in $66.7 \%$, serum lipase in $33.3 \%$ and ALP in $33.3 \%$. Their diagnosis were confirmed by ultrasonography. They were managed conservatively and were delivered with good outcome. .,2,4,6,7 $^{-1}$

\section{Surgical causes}

\section{Acute cholecystitis}

There were three cases of acute cholecystitis. The gestation age was varying from first trimester to third trimester. They presented with complaints of pain abdomen with right hypochondrial tenderness and one among them had complaints of itching over palms and soles. The diagnosis was confirmed by ultrasonography in all three women. The identified etiology of acute cholecystitis was multiple calculus. Among them, one woman was managed conservatively and rest were managed surgically by laparoscopic cholecystectomy. Of the two women managed surgically, one had undergone laparoscopic cholecystectomy and the other was initially treated with EUS and ERCP with stenting and later was taken for laparoscopic cholecystectomy, CBD exploration and T tube insertion due to worsening pain, fever and jaundice in post-operative period and was observed in HICU. They delivered at term with good maternal and fetal outcome. ${ }^{1-4}$

\section{Acute appendicitis}

There were two cases of acute appendicitis. They presented at second trimester with complaints of pain abdomen and vomiting.

Table 1: Distribution of cases based on trimester at the time of presentation, clinical presentation, imaging technique, maternal mortality.

\begin{tabular}{|c|c|c|c|c|c|c|}
\hline \multicolumn{3}{|r|}{ Cases } & I trimester & II Trimester & III Trimester & Total \\
\hline \multicolumn{3}{|l|}{ Total } & $1(5.5 \%)$ & $9(50 \%)$ & $8(44.5 \%)$ & $18(100 \%)$ \\
\hline \multicolumn{3}{|c|}{ Acute pancreatitis } & 0 & $0(0 \%)$ & $3(37.5 \%)$ & $3(16.6 \%)$ \\
\hline & \multicolumn{2}{|c|}{ Acute cholecystits } & $1(100 \%)$ & $1(11.1 \%)$ & $1(12.5 \%)$ & $3(16.6 \%)$ \\
\hline & \multicolumn{2}{|c|}{ Acute appendicitis } & 0 & $2(22.2 \%)$ & $0(0 \%)$ & $2(11.1 \%)$ \\
\hline Cases & \multicolumn{2}{|c|}{ Intestinal malrotation } & 0 & $0(0 \%)$ & $2(25 \%)$ & $2(11.1 \%)$ \\
\hline & \multicolumn{2}{|c|}{ Uterine rupture } & 0 & $2(22.2 \%)$ & $0(0 \%)$ & $2(11.1 \%)$ \\
\hline & \multicolumn{2}{|c|}{ Rudimentary horn rupture } & 0 & $4(44.5 \%)$ & $0(0 \%)$ & $4(22.4 \%)$ \\
\hline & \multicolumn{3}{|c|}{ Ovarian torsion } & $0(0 \%)$ & $2(25 \%)$ & $2(11.1 \%)$ \\
\hline \multicolumn{4}{|c|}{ Characteristics } & \multicolumn{2}{|c|}{ Number of cases } & Percentage \\
\hline \multirow{6}{*}{\multicolumn{2}{|c|}{$\begin{array}{l}\text { Clinical } \\
\text { presentation }\end{array}$}} & \multicolumn{2}{|c|}{ Pain abdomen only } & 3 & \multicolumn{2}{|c|}{$16.6 \%$} \\
\hline & & \multicolumn{2}{|c|}{ Pain abdomen and vomiting } & 8 & \multicolumn{2}{|c|}{$44.4 \%$} \\
\hline & & \multicolumn{2}{|c|}{ Pain abdomen in shock } & 7 & \multicolumn{2}{|c|}{$39 \%$} \\
\hline & & \multirow{3}{*}{$\begin{array}{l}\text { Associated } \\
\text { tenderness }\end{array}$} & Epigastric & 2 & \multicolumn{2}{|c|}{$11 \%$} \\
\hline & & & Right Hypochondrium & 3 & \multicolumn{2}{|c|}{$16.6 \%$} \\
\hline & & & Right illac fossa & 1 & \multicolumn{2}{|c|}{$5.6 \%$} \\
\hline \multirow{3}{*}{\multicolumn{2}{|c|}{ Diagnosis }} & \multicolumn{2}{|l|}{ Ultrasound } & 10 & \multicolumn{2}{|c|}{$55.6 \%$} \\
\hline & & \multicolumn{2}{|l|}{ MRI } & 2 & \multicolumn{2}{|c|}{$11.1 \%$} \\
\hline & & \multicolumn{2}{|l|}{ On-Table } & 6 & \multicolumn{2}{|c|}{$33.3 \%$} \\
\hline \multicolumn{4}{|c|}{ Maternal mortality } & 1 & \multicolumn{2}{|c|}{$6 \%$} \\
\hline
\end{tabular}


Right iliac fossa tenderness was elicited in only one woman. Diagnosis was confirmed with ultrasonography in one woman and the other required higher imaging (MRI).
They were treated surgically by laparoscopic appendicectomy and delivered at term with good maternal and fetal outcome. ${ }^{1-5}$

Table 2: Characteristics of various cases showing clinical presentation, diagnostic tool, management and outcome of the cases.

\begin{tabular}{|c|c|c|c|c|}
\hline Cases & Clinical presentation & Diagnosis & Management & Outcome \\
\hline $\begin{array}{l}\text { Acute } \\
\text { pancreatitis }\end{array}$ & $\begin{array}{l}\text { Pain abdomen, } \\
\text { vomiting, epigastric } \\
\text { tenderness }(100 \%)\end{array}$ & $\begin{array}{l}\text { Raised serum amylase } \\
(66.7 \%) \text {, serum lipase } \\
(33.3 \%) \text {, ALP }(33.3 \%) \\
\text { USG }(100 \%)\end{array}$ & Conservative $(100 \%)$ & $\begin{array}{l}\text { Good } \\
\text { Delivered by LSCS. }\end{array}$ \\
\hline $\begin{array}{l}\text { Acute } \\
\text { cholecystitis }\end{array}$ & $\begin{array}{l}\text { Pain abdomen with } \\
\text { right hypochondrial } \\
\text { tenderness }(100 \%)\end{array}$ & USG $(100 \%)$ & $\begin{array}{l}\text { Conservative }(33.3 \%) \\
\text { surgical }(66.7 \%) \text { by } \\
\text { laparoscopic } \\
\text { cholecystectomy }\end{array}$ & $\begin{array}{l}\text { Good } \\
\text { Delivered at term }\end{array}$ \\
\hline $\begin{array}{l}\text { Acute } \\
\text { appendicitis }\end{array}$ & $\begin{array}{l}\text { Pain abdomen and } \\
\text { vomiting (100\%), } \\
\text { right iliac fossa } \\
\text { tenderness }(50 \%)\end{array}$ & $\begin{array}{l}\text { USG }(50 \%) \\
\text { MRI }(50 \%)\end{array}$ & $\begin{array}{l}\text { Laparoscopic } \\
\text { appendicetomy }(100 \%)\end{array}$ & $\begin{array}{l}\text { Good } \\
\text { Delivered at term }\end{array}$ \\
\hline \multirow[b]{2}{*}{$\begin{array}{l}\text { Intestinal } \\
\text { Malrotation }\end{array}$} & $\begin{array}{l}\text { Pain abdomen with } \\
\text { vomiting, } \\
\text { history of repeated } \\
\text { admission for same }\end{array}$ & $\begin{array}{l}\text { USG inconclusive } \\
\text { On-table diagnosis }\end{array}$ & $\begin{array}{l}\text { Exploratory } \\
\text { laparotomy with LSCS } \\
\text { and LADD procedure, } \\
\text { intra-operative } \\
\text { findings: Intestinal } \\
\text { malrotation and } \\
\text { midgut volvulus. }\end{array}$ & Good \\
\hline & $\begin{array}{l}\text { Persistent pain } \\
\text { abdomen and loss of } \\
\text { consciousness, } \\
\text { tachycardia, } \\
\text { unrecordable blood } \\
\text { pressure, tensely } \\
\text { distended abdomen } \\
\text { with diffuse } \\
\text { tenderness and absent } \\
\text { fetal heart sound. }\end{array}$ & $\begin{array}{l}\text { Bedside USG revealed } \\
\text { gross fluid in the } \\
\text { peritoneum with suspect of } \\
\text { uterine rupture. }\end{array}$ & $\begin{array}{l}\text { Laparotomy with } \\
\text { LSCS and derotation } \\
\text { of intestine and band } \\
\text { release. } \\
\text { Intra-operative } \\
\text { findings: blood stained } \\
\text { foul smelling ascitic } \\
\text { fluid, intact uterine } \\
\text { wall and acute } \\
\text { intestinal obstruction } \\
\text { with midgut volvulus. }\end{array}$ & $\begin{array}{l}\text { Maternal death with } \\
\text { intra-uterine fetal } \\
\text { demise }\end{array}$ \\
\hline $\begin{array}{l}\text { Uterine } \\
\text { rupture }\end{array}$ & $\begin{array}{l}\text { Pain abdomen in } \\
\text { shock }(100 \%), \text { history } \\
\text { of previous LSCS } \\
(100 \%), \text { history of } \\
\text { MTP pill in one } \\
\text { woman }\end{array}$ & $\begin{array}{l}\text { USG }(50 \%) \\
\text { On table diagnosis }(50 \%)\end{array}$ & $\begin{array}{l}\text { Laparotomy with } \\
\text { uterine repair }\end{array}$ & Good \\
\hline $\begin{array}{l}\text { Rudimentary } \\
\text { horn rupture }\end{array}$ & $\begin{array}{l}\text { Pain abdomen in } \\
\text { shock }(100 \%)\end{array}$ & $\begin{array}{l}\text { USG }(50 \%) \\
\text { MRI }(25 \%) \\
\text { On table diagnosis }(25 \%)\end{array}$ & $\begin{array}{l}\text { Laparotomy with } \\
\text { hemihysterectomy }\end{array}$ & Good \\
\hline $\begin{array}{l}\text { Ovarian cyst } \\
\text { torsion }\end{array}$ & $\begin{array}{l}\text { Pain abdomen with } \\
\text { vomiting }(100 \%)\end{array}$ & $\begin{array}{l}\text { USG }(50 \%) \text { and MRI } \\
(50 \%) \text { : ovarian cyst with } \\
\text { no evidence of torsion } \\
\text { On table - confirmed } \\
\text { torsion of ovarian cyst }\end{array}$ & $\begin{array}{l}\text { Elective LSCS with } \\
\text { concurrent cystectomy } \\
\text { in one woman, } \\
\text { emergency LSCS with } \\
\text { left partial } \\
\text { salpingectomy in other } \\
\text { woman }\end{array}$ & Good \\
\hline
\end{tabular}




\section{Malrotation}

There were two cases of malrotation in the study population. One woman had presented with pain abdomen and vomiting with history of repeated admission for same complaints. On examination, diffuse tenderness was noted over whole abdomen. She was planned for surgical management in view of persistent pain abdomen not relieving on medication and underwent exploratory laparotomy with LSCS and LADD procedure with intraoperative findings revealing the diagnosis of intestinal malrotation and midgut volvulus. Another woman was referred in view of persistent pain abdomen, breathlessness and loss of consciousness with persistent tachycardia and hypotension. Examination revealed tachycardia, unrecordable blood pressure, tensely distended abdomen with diffuse tenderness and absent fetal heart sound. Bedside USG revealed gross fluid in the peritoneum with suspect of uterine rupture. Patient was taken emergency laparotomy and proceeded with LSCS and derotation of intestine and band release. Intra-operative findings revealed blood stained foul smelling ascitic fluid, intact uterine wall and acute intestinal obstruction with midgut volvulus. During the procedure, patient had cardiac arrest and was resuscitated and started on inotropes. Patient was shifted to ICU where she had cardiac arrest again and couldn't be revived. ${ }^{1,2,3,4,8}$

\section{Obstetric and gynaecological causes}

\section{Uterine rupture}

There were two cases of second trimester uterine rupture. The risk factor identified in both women was previous LSCS wherein one of them had history of MTP pills intake. Clinical presentation was pain abdomen in shock in both women $(100 \%)$. One woman was diagnosed with the help of ultrasonography and the other was diagnosed on table during surgery. They were managed surgically by emergency laparotomy with uterine repair and recovered well. ${ }^{9,10}$

\section{Rudimentary horn rupture}

There were four cases of rudimentary horn rupture. Among them, two were primiparous and other were multiparous. Clinical presentation was pain abdomen in shock in second trimester in all women. Diagnosis was confirmed by ultrasonography in two cases, MRI in one woman where USG revealed suspect of rudimentary horn pregnancy with impending rupture and one woman was diagnosed on table during surgery. They were surgically managed by Laparotomy and hemihysterectomy with intra-operative confirmatory diagnosis of rudimentary horn rupture. ${ }^{11,12}$

\section{Ovarian cyst torsion}

There were two cases of ovarian cyst torsion. They presented in third trimester with pain abdomen and vomiting. Among them, one woman gave history of diagnosis of ovarian cyst in early trimester. Imaging was done which revealed ovarian cyst with no evidence of torsion in both women. One woman was taken for elective LSCS with concurrent cystectomy in view of torsion noted during surgery and the other was taken for emergency LSCS with Left partial salpingectomy done in view of nonreassuring fetal heart status where intra-operatively, Left fimbrial necrotized cyst with torsion of 5 turns $\sim 5 \times 5 \mathrm{~cm}$ was noted..$^{13,14}$

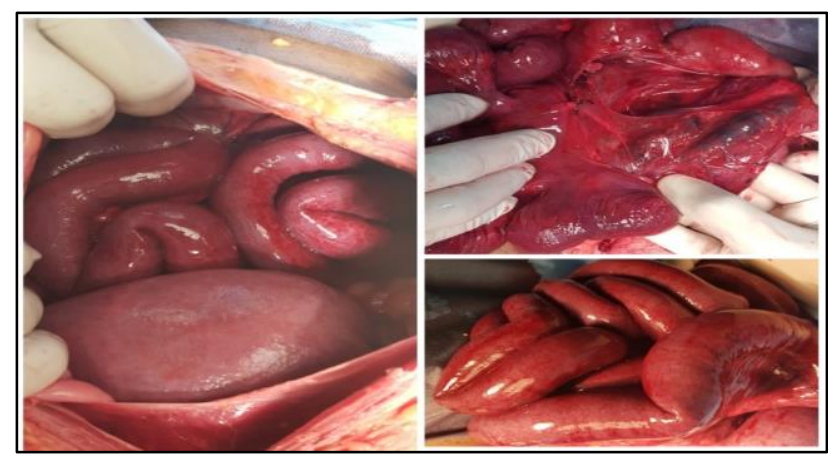

Figure 1: Acute intestinal obstruction with midgut volvulus.

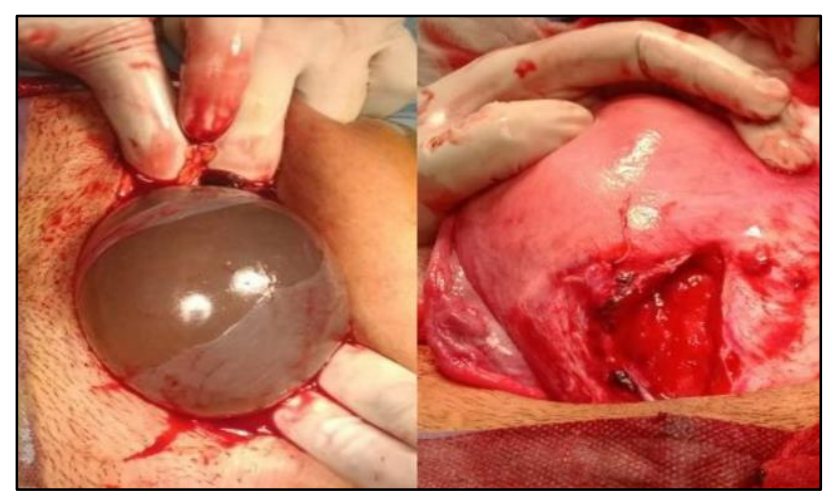

Figure 2: Second trimester uterine rupture with intact gestational sac.

\section{DISCUSSION}

In our study, we aimed to give an overview of the causes of acute abdomen during pregnancy with special attention to the clinical presentation and diagnostic dilemma of such cases. It was an observational study done over a period of 3 years in Bangalore Baptist Hospital which included all the pregnant women who presented with acute abdomen.

The study population included eighteen pregnant women who presented with acute abdomen. The age distribution (years) showed majority of women $(50 \%)$ in the range of 21-25. The cases were analysed based on the trimester, clinical presentation and diagnostic methods utilized. Trimester- wise distribution showed $5.5 \%$ women in first trimester, 50\% women in second trimester and $44.5 \%$ women in third trimester. The case distribution based on the trimester were analysed. There was one case of acute 
cholecystitis in first trimester. During second trimester, there were cases of acute appendicitis (22.2\%), acute cholecystitis $(11.1 \%)$, uterine rupture $(22.2 \%)$ and rudimentary horn rupture $(44.5 \%)$. During third trimester, there were cases of acute pancreatitis $(37.5 \%)$, acute cholecystitis (12.5\%), intestinal malrotation (25\%), ovarian torsion $(25 \%)$.

The clinical presentation among the study population showed only pain abdomen in $16.6 \%$ and associated features like vomiting in $44.4 \%$, shock in $39 \%$ and abdominal tenderness in $33.3 \%$. The diagnosis was confirmed with ultrasonography in $55.6 \%, 11.1 \%$ women required higher imaging like MRI and $33.3 \%$ women were diagnosed on table. The women were managed medically and surgically based on the diagnosis and feto-maternal condition. Among the study population, 16 women (94\%) had good maternal and fetal outcome. There was one maternal mortality $(5.5 \%)$ with intra-uterine fetal demise which was a case of malrotation of intestine. ${ }^{4}$

Diagnosis and treatment of acute abdomen in pregnancy depends on the specific situations. Individualized approach is the best while evaluating a pregnant woman. Diagnosis should be confirmed with appropriate investigations to prevent delay in the management. Higher order imaging like MRI can be used as MRI is considered to be safe in pregnancy. Early intervention is recommended to reduce the maternal fetal complications.

\section{CONCLUSION}

Diagnosis and treatment of acute abdomen in pregnancy should be individualized. Good clinical acumen is essential for ordering early diagnostic test in acute abdomen in pregnancy. Appropriate intervention should be undertaken at the earliest to reduce the maternal and fetal complications.

Funding: No funding sources

Conflict of interest: None declared

Ethical approval: Not required

\section{REFERENCES}

1. Chhabra S, Borkar P. Essentialities of knowledge of whys and whats of acute abdomen during pregnancy. J Mahatma Gandhi Inst Med Sci. 2013;18:97-102.

2. Augustin G, Majerovic M. Non-obstetrical acute abdomen during pregnancy. Eur J Obstet Gynecol Reprod Biol. 2007;131(1):4-12.
3. Shervington J, Cox C. Abdominal pain in pregnancy: diagnosis, surgery and anaesthesia. The Obstetrician \& Gynaecologist. 2000;2.

4. Rao PR, Chakravarthy GR, Sufiya S, Kumar BA, Kalyan KASSN. Clinical Study of Non Traumatic Acute Abdomen in Female Patients. IOSR Journal of Dental and Medical Sciences (IOSR-JDMS). 2017;16(3):34-47.

5. Weston P, Moroz P. Appendicitis in pregnancy; how to manage and whether to deliver. Obstet Gynaecol. 2015;17:105-110.

6. Tang SJ, Rodriguez-Frias E, Singh S, Mayo MJ, Jazrawi SF, Sreenarasimhaiah $J$ et al. Acute pancreatitis during pregnancy. Clin Gastroenterol Hepatol. 2010;8(1):85-90.

7. Nandini G, Balekuduru A, Jyothi GS, Fernandes J, Shivananjaiah C. Acute Pancreatitis in Pregnancy? Successful Outcome. International Journal of Science and Research (IJSR). 2015;4(8):650-51.

8. Kharka L, Sarma D, Pai M, Sehgal K, Nambiar, J. Malrotation Of Gut With Volvulus In Early Pregnancy. National Journal of Integrated Research in Medicine. 2013;4(5):105-106.

9. Bharatnur S, Hebbar S, Shyamala G. Early second trimester uterine scar rupture. BMJ Case Rep. 2013;2013:bcr2013200960.

10. Hofmeyr GJ, Say L, Gülmezoglu AM. WHO systematic review of maternal mortality and morbidity: the prevalence of uterine rupture. BJOG. 2005;112(9):1221-8.

11. Thakur S, Sood A, Sharma C. Ruptured noncommunicating rudimentary horn pregnancy at 19 weeks with previous cesarean delivery: a case report. Case Rep Obstet Gynecol. 2012;2012:308476.

12. Lallar M, Nandal R, Sharma D. Unruptured rudimentary horn pregnancy presenting with acute haemoperitoneum with combined intrauterine pregnancy: A case report. Iran J Reprod Med. 2015;13(1):49-52.

13. Koumoutsea VE, Gupta M, Hollingworth A, Gorry A. Ovarian Torsion in the Third Trimester of Pregnancy Leading to Iatrogenic Preterm Delivery. Case Rep Obstet Gynecol. 2016; 2016:8426270.

Cite this article as: Abhirami GR, Sathyavani C, Patil RN. Acute abdomen in pregnancy: a case series on clinical presentation and diagnostic dilemma. Int $\mathbf{J}$ Reprod Contracept Obstet Gynecol 2021;10:742-6. 